\title{
The Humanitarian Assistence Role of Aksi Cepat Tanggap (ACT) Toward Victims of Syrian Conflict in Syria and Turkey From 2012 To 2018
}

\author{
Rahmadi $^{1}$, Yon Mahmudi ${ }^{2}$, Muhammad Syauqillah ${ }^{3}$ \\ \{1 rahmadi.ghamra@gmail.com, ${ }^{2}$ machmudi@ui.ac.id, ${ }^{3}$ muhamadsyauqillah@ui.ac.id $\}$ \\ ${ }^{1,2,3}$ School of Strategic and Globa Studies, Universitas Indonesia, Indonesia
}

\begin{abstract}
This research discusses the involvement of Indonesian nongovernmental organisations (NGO) in the Syrian civil war via a case study. Specifically, it looks into the humanitarian aid role implemented by Aksi Cepat Tanggap (ACT) in assisting victims of the Syrian conflict from 2012 to August 2018. This study is a qualitative research and utilised the descriptive analysis method. Data were collected from in depth interview with relevant authorities and the literatures. This topic was viewed through the concepts of Humanitarian Action Principle, Human rights, and International Humanitarian Law. The study discovers that as an NGO, ACT has delivered the humanitarian assistence to those whom are victims of the Syrian civil war through its structural roles in the form of charity programs and social empowerment. However, the largest focus was given to the charity programs. A good framework of cooperation was also established among the Turkish Government, local NGO's both in Turkey and Syiria and Aksi Cepat Tanggap itself, which contributed positively to successful distribution of humanitarian aid towards the conflict victims. In light of these findings, this study recommends the need for ACT to further strengthen its commitment in providing humanitarian assistance and develop more the program to ensure that future humanitarian assistence programs be more effective.
\end{abstract}

Keywords: Humanitarian Aid Role, Aksi Cepat Tanggap, NGO, Turkey, Syria, conflict.

\section{INTRODUCTION}

Following the emergence of Arab Spring across the Middle East in 2010, the Syrian conflict is yet to see its conclusion. In armed conflicts, victims affected by the war are not only limited to the conflicting parties, but also civilians, especially children, women, and the elderly (vulnerable groups). The UN stated that the death toll from the Syrian conflict has reached more than 400 thousand. The European Civil Protection and Humanitarian Aid Operations (2018) reported that 13 million victims of the conflict are in dire need of humanitarian aid. Of that figure, 6 million are children. Based on data from UNHCR, as of August 2018 the number of internal displaced persons (IDP) in Syria amounted to 6.6 million. More than 5.6 million individuals have left the country and sought refuge in neighbouring nations, such as Turkey, Lebanon, Jordan, and European countries. 
Rules concerning civilian and disputing parties in conflict situations have long existed. The Chinese general Sun Tzu, in his book The Art of War, was among the earliest initiator of such rules (Rysaback-Smith, 2015). The Roman and Greek Empires have also practiced them (Eleanor Davey, 2013). In the 20th century, the International Humanitarian Law and Geneva conventions, including their additional protocols, have represented the modern consensus regarding the proper treatment of civilians, wounded soldiers, and prisoners during the times of conflict. Humanitarian aid distribution is one of the terms covered by the Fourth Geneva Convention of 1949 and Additional Protocols I and II of 1977. These rules are intended to ensure the fulfilment of basic rights of conflict-affected civilians.

Four basic principles coordinate the activities of donor agencies, both government and nongovernment organizations (NGO). These four principles were passed by the United Nations General Assembly in 1991 (humanity, impartiality, and neutrality) and 2004 (independence). They then form the principal reference of the humanitarian acts of the International Committee of the Red Cross (ICRC) and humanitarian NGOs (United Nations, 1991 \& 2004., ICRC, 1994). In addition to international humanitarian law, the Universal Declaration of Human Rights of 1945 also plays a significant role in protecting the rights of civilians in cases of conflict and non-conflict. In conflict situations such as in Syria, humanitarian aid is vital in ensuring the fulfilment of the rights of Syrian civilians affected by the conflict, such as the right to live and the right to have access to humanitarian aid. Humanitarian aid is commonly the only solution to prevent hunger and death. Humanitarian aid encompasses the act of distributing products and services vital for the survival of conflict-affected parties. Authorities must allow and protect the inflow of aid intended for the safety of the conflict victims.

The Syrian conflict has gathered international attention, one of which comes from Indonesia. Indonesian NGOs, such as Aksi Cepat Tanggap (ACT), Pos Keadilan Peduli Umat Human Initiative (PKPU- HI), Dompet Duafa, and Rumah Zakat, have actively distributed humanitarian aid to local refugee camps in Syrian and the Syria-Turkey border. The involvement of humanitarian NGO in conflicts such as in Syria is essential, as NGOs are nonstate actors that found their policies on the principles of humanity, neutrality, impartiality, and independence (Rahmawati, 2015).

In this study, the author focuses on the roles and strategies of ACT in distributing its aid to Syrian conflict victims, as ACT echoes a massive amount of voluntary movement and sympathy for the conflict. True to its name, Aksi Cepat Tanggap (Quick Response Action) has always rapidly provided humanitarian services and responded to every needs of the Syrian refugees since the beginning of the conflict in 2011. Until 2018, ACT has sent the SOS team (Sympathy of Solidarity) 14 times to Syria, Turkey, and Syria's neighboring countries to respond to the emergencies of the Syrian conflict victims. The aid comprises comestibles, medicines, medical teams, education, winter clothes, operational support for bread factories, community kitchens, and construction of shelters and houses. ACT uses $64 \%$ of its income for its global humanitarian program, including Syria (ACT, 2018).

Aksi Cepat Tanggap is an Indonesian-based non-profit humanitarian NGO. Among its programs are emergency response, post-disaster rehabilitation, social empowerment, and social development. ACT expands its network through overseas offices and representative persons (volunteer representative). In a local scale, the ACT network has reached 30 provinces and 100 regencies and cities in the form of branch offices and volunteer network (Indonesian Volunteer Society/MRI). On a global scale, ACT has covered more than 43 nations and has a representative office in Turkey. ACT is also part of the Turkey-based Union of NGOs of the Islamic World (UNIW). Additionally, ACT also cooperates with various international humanitarian NGOs and government institutions, such as Humanitarian Relief Foundation (IHH), Disaster and 
Emergency Management Presidency of Turkey (AFAD) , Al-barakah Foundation, and Dayanisma Foundation . In addition to humanitarian collaborations, the partnered organizations are also viewed as potential donor institutions for ACT's humanitarian acts in and outside of Syria.

\section{HUMANITARIAN ROLE OF ACT TOWARD CONFLICT VICTIMS IN SYRIAN AND TURKEY}

\subsection{Purpose and Motivation of Act}

Human solidarity forms one of the main arguments of ACT to enter Syria. Together with other international NGOs, ACT supplies emergency aid to conflict victims in Syria and Turkey, both of which are the main focus of ACT. In its entire humanitarian act, ACT always upholds three values that form its framework: humanity, volunteerism, and philanthropy (ACT Profile, 2018). NGOs must adhere to the principles of humanitarian act in distributing aid so that they remain within the framework stipulated by international humanitarian law. The implementation of these principles also facilitates the negotiation between conflict actors and humanitarian workers to accept and respect the presence of humanitarian organizations during their mission in Syria. According to the Geneva Convention, the humanitarian act is found on four principles: humanity, impartiality, neutrality, and independence. Humanitarian principles are the fundamental commitment of humanitarian work carried out by the actors of humanitarian action (Michael Barnett and Thomas Weiss, 2008). The neutrality principle requires humanitarian action to not side with any of the conflicting parties. The impartiality principle denotes that the humanitarian work should not discriminate by either nationality, ethnicity, religion, gender, or race when helping those in need. The independence principle means that the humanitarian action is free from military, economy, or political interests (Brubacher, 2003).

ACT incorporates the fundamental humanitarian principles in all of its humanitarian programs. In 1994, these principles were enforced with the formulation of the Code of Conduct for the International Red Cross and NGOs to drive the implementation of the principles in the field (Kusuma, 2010).

According to Archer (1992), the role of international organizations can be divided into three categories. First, as a meeting arena where member countries talk and discuss about their issues outside of their borders, with the intention of gaining international attention. Second, as an instrument used by member countries to achieve certain goals in line with their foreign policy objectives. Third, as an independent actor that can make decisions without the influence of power or pressure from external organizations. In relation with the abovementioned roles, ACT, together with UNIW members, is actively involved in discussions, expositions, and other humanitarian activities concerning the Syrian crisis (Guritno, 2018).

\subsection{Humanitarian Aid Strategy of ACT toward Conflict Victims in Syria and Turkey}

\subsubsection{Media Publication}

In the era of globalization, the media play a vital part. Numerous aspects occurring in the virtual world often influence real world aspects, as exemplified by the Alan Kurdi Effect. The reporting of Alan Kurdi's death across social media has influenced the global public opinion. Following the tragedy, debates on refugees spread across Europe, and pressure to the European 
Union to open its borders escalated. Germany responded quickly and increased its acceptance of Syrian asylum seekers (Damayanti, 2017).

Humanitarian NGOs take advantage of such tragedies to rally human solidarity actions. One of ACT's activities to raise humanitarian funding for Syrian refugees is massive media publication, especially in Indonesia. ACT actively campaigns and collaborate with Indonesia's national mass media outlets, be it television, such as Metro TV, TV One, and Kompas TV, or print, such as Republika, Kompas, and Hidayatullah. ACT utilizes the media to promote its humanitarian activities at disaster locations. In addition, ACT also makes use of social media, which tends to be effective, considering that Indonesian internet users amount to 143 million people or more than $50 \%$ of the population (Kompas, 2018). Currently, ACT's Facebook and Instagram pages are followed by respectively 1.6 million and 325 thousand users.

Firdaus Guritno, a member of the Middle East - Syam \& Africa Desk Region (2018) stated that ACT employs two strategies to optimize their fund-raising activities on mass and social media. First, ACT must draw on moments of humanitarian tragedy well. In other words, if a disaster were to occur, ACT's field and media teams must quickly move enter the location and publish the real situation occurring there. From this publication, ACT can gain the sympathy of the public. As a result, its fund-raising machine can work optimally. Second, it ACT must create creative and interesting contents that can influence the public opinion of a given tragedy.

Una Osili and Cagla Okten (2015) assert that the above method can psychologically influence the Indonesian society, seeing that philanthropic culture is deeply ingrained within it, especially among Indonesian Muslims. ACT has carried out this strategy for years to accumulate local and international support, and to increase public awareness on the importance of solidarity and volunteerism in conflict situations, during which it acts as an agent of humanitarian protection. In its social campaign, ACT frequently includes hashtags with humanitarian jargons and Islamic values, which are expected to move the philanthropic conscience of local and global Muslims.

ACT's campaign on mass and social media is proven to be effective. Its revenue constantly increases year-on-year. In 2012, ACT generated an income of more than Rp32 billion, while in 2017, the amount had climbed considerably to Rp150 billion. ACT targets an income of Rp300 billion for 2018. Funding mainly comes from individual donors and firms' corporate social responsibility (CSR) allocations.

\subsubsection{Distribution of Humanitarian Aid}

Both international humanitarian law and human rights regulate humanitarian aid distribution so as to guarantee the fulfilment of civilian rights. ACT concentrates its humanitarian aid projects on refugee camps in Syria and Turkey. This decision was made due to the high number of local refugees in Syria, which amounted to 6.6 million individuals, and Turkey, which totaled to 3.5 million individuals (UNCHR Syria, 2018). Before distributing any assistance, ACT's Global Humanity Response team will first conduct a research on which region really needs emergency aid and what assistance is most required. For refugee camps in Syria and Turkey, ACT prioritizes the distribution of basic needs such as food, clothes, medicines, and medical workers, as these are the most demanded. ACT also has some small-scale social development projects in Turkey.

Since 2012, ACT has sent the Sympathy of Solidarity (SOS) Global Action Team 14 times. Some regions reached by ACT in Syria are Aleppo, Idlib, Kilis, Ghouta, A'zaz District, Ariha, Al-Atareb, and other districts. In Turkey, ACT has covered almost every camp in 10 cities, such as Gaziantep, Yayladagi, Reyhanle, and Adanalioglu (ACT Program, 2018). Throughout the 
distribution process, ACT also collaborates with local Syrian and Turkish NGOs to facilitate aid supply to conflict-affected regions in Syria. Local partners are more aware of real field situations. They are also more informed of the types of assistance needed and which regions require emergency responses. In emergency conditions, the recipient of ACT benefits are all refugees requiring emergency assistance. As for its regular programs, ACT specifies its recipient as the disabled, orphan, children, women, and family with many dependents. ACT's humanitarian programs in Syria and Turkey consist of emergency, relief, and social development programs. They are detailed as follows.

\section{Emergency Response}

Distribution of basic food needs is an option taken by ACT, seeing that food supply is rare and the high price of foodstuff at refugee camps in Syria and Turkey. ACT has a variety of food supply programs according to the needs of a given refugee camp, such as operating costs support for bread factories and supplying to community kitchens.

\section{a. Bread Factory}

Bread is the staple food of Syrians, Turks, and Middle Eastern people in general. The longlasting political crisis in Syria has pushed humanitarian elements to come up with a solution that can support the life of refugees inside and outside of Syrian borders. Since the commencement of the civil war, the prices of basic food necessities have rocketed, and bread factories are left by their refuging owners. These factors motivate ACT to cooperate with several bread factories. Indonesian citizens, through ACT, support the operations of two bread factories, which are located in Idlib and Kilis. Both cities are the primary destination of refugees. The factories are able to produce 157 thousand loaves of bread per day. Every day, ACT distributes 120 thousand loaves to a region near the Turkey-Syria border, Kilis. Meanwhile, 37 thousand loaves are distributed to Azaz, a rural area near Aleppo, and Idlib, Syria (ACT, 2018)

\section{b. Community Kitchen}

ACT also supplies food ingredients to community kitchens in Syria and Turkey, especially during the occurrence of massive conflict and increased inflow of refugees, local or otherwise. For example, during the tragedy of Goutha 2018, 400 thousand individuals were trapped in Ghouta. They hid in bunkers under their homes to avoid the attacks. The President of ACT, Ahyudi, stated that ACT built a community kitchen in the region to help the remaining population. He explained that ACT has five partners in Ghouta, and each partner built around four community kitchen camps. ACT finances every kitchen. Each day, the kitchens produce around 20 thousand packages of food. However, the amount is still insufficient to satisfy the demand of Ghouta residents. ACT stated that there are some obstacles to bring in food ingredients to Ghouta, as it is not possible to transport them using truck convoys from Turkey. As a result, ACT has to collaborate with local humanitarian volunteers that have worked in Syria for years. Food ingredients are available, but prices are high, at times 70 percent more expensive than normal prices. With this issue in mind, ACT decided to initiate those community kitchens to prevent the victims from hunger (Guritno, 2018)

\section{c. Humanity Card}

ACT created a creative program with the provision of an ATM-like humanity card for 300 refugee families in Mersin on the Turkey-Syria border. The program was implemented in December 2016. Each month, ACT will automatically credit the card with around USD 40. The card is intended for the purchase of basic necessities and can be used with market partners of ACT. This solution is seen as an effective method to allow the refugees to choose their own necessities. They also do not have to queue to obtain their needs. In Syria, this program is 
expected to be launched in 2018, targeting 200 families based on ACT's assessment data (Guritno, 2018)

\section{d. Humanitarian Ship}

The ceaseless, intense Syrian conflict has inspired ACT to send food ingredients in a large scale to ensure the availability of food for the victims. On 21 April 2017, ACT sent a humanitarian ship to bring 1,000 tons of rice from Belawan, Indonesia. The ship covered a distance of 5,059 mi or 9,369 km to Assan Port, Iskenderun, Hatay Province, Turkey. The rice was divided into two distribution agendas. The first 500 tons were distributed to refugee camps in Syria, reaching 40 thousand recipients. The distribution area covered Aleppo, Hama, and Idlib. The remaining 500 tons were distributed to areas along the Syria-Turkey border. Sea fright is chosen as a shipping option as it enables large-scale transportation of assistance. Additionally, ACT also established the Indonesian Humanitarian Center (IHC) in Reynhali as a logistics and warehousing center for the organization (Guritno, 2018)

\section{Social Empowerment}

Besides emergency assistance, ACT also plays a role in social development. Although still small-scaled, the programs are expected to give a positive influence on Syrian conflict victims.

\section{a. Education}

Education is a child empowerment program delivered by ACT. This program functions as a post-conflict rehabilitation center for children who have lost their families, environment, friends, homes, schools, and childhood. As widely reported, 2016 is the most critical year of humanitarian tragedy in Syria. Armed groups also targeted education areas. The United Nations Office for the Coordination of Humanitarian Affairs (OCHA) reported that in 2016, more than two million Syrian children and teenagers were out of school. One out of four schools are damaged, destroyed, or not operating due to the insufficient number of educators. As a result, on February 2016, ACT created the Lights for Syria program. ACT constructed schools at Alaiykha Camp to help educate Syrian children. ACT also provided school facilities at Salahuddin Camp in Idlib Province. In Reyhanle, a Turkish city on the Turkey-Syria border, there are around 1,250 Syrian children refugees who require education aid. ACT constructed six schools in the region. ACT's support included operating costs for the school, building lease, and student shuttle fees (Guritno, 2018).

Schools for children in the refugee camp is important to prevent them from joining with the armed groups. At school, they are also taught how to save themselves from bombs, gunshots, land mines, and other dangers. Children separated from their parents, environment, and playing time, and grow without any education will inflict negative impact on society. Due to their physical and psychological immaturity, children should receive particular treatment so they can grow and develop well, physically, mentally, and spiritually.

\section{Relief Program}

\section{Construction of Houses}

Among the relief programs supported by ACT is the construction of housing complex for Syrian orphans in Idlib. ACT is one of the donators for the program. IHH, one of ACT's partners and main stakeholder of the project, is the main executor of the program. This program is expected to transfer refugees from emergency camps into the housing complex. Construction began in early 2017 and is still in progress. Donors target the construction of 100 houses in the complex. A house consists of four to six habitable rooms, which means that each building can 
accommodate four to six households. The cost to construct each house is around Rp1.5 billion (Guritno, 2018)

\section{CONCLUSIONS}

Non-profit NGOs based on humanitarian principles are an important actor in increasing international awareness to sympathize and react to global humanitarian disasters, such as the Syrian conflict. The humanitarian acts of ACT Indonesia offer a positive effect on Syrian conflict victims, both in and outside of Syria. In its activities in Syria, ACT implements the four humanitarian principles of humanity, neutrality, impartiality, and independence. These principles must be implemented to ensure that humanitarian aid can be continuously supplied to the victims throughout the Syrian conflict.

\section{ACKNOWLEDGEMENT}

This research based on grant scheme of PITTA (Publikasi International Terindeks untuk Tugas Akhir) or also known as Indexed International Publications for Final Projects toward Universitas Indonesia students. Thank you to The Directorate of Research and Community Engagement of Universitas Indonesia (DRPM UI).

\section{REFERENCES}

[1]. Guritno, Firdaus. (2018, August 2). Bantuan Kemanusiaan Aksi Cepat Tanggap (ACT) ke Suriah. (Rahmadi, Interviewer)

[2]. Avalis, Nanda. (2018, September 26). Peran Kemanusiaan ACT di Suriah. (Rahmadi, Interviewer)

[3]. Lubis, T. M. (1993). In search of Human Rights Legal-Political Dilemmas of Indonesia's New Order, 1966-1990. Jakarta: Gramedia.

[4]. Michael Barnett and Thomas Weiss. (2008). Humanitarian in Question: Politics, Power, Ethic. New York: Cornell University Press.

[5]. Creswell, J. W. (2010). Research Design: Pendekatan Kualittatif, Kuantitatif, dan Mixed. Yogyakarta: Pustaka Pelajar.

[6]. Damayanti, Y. (2017). The Alan Kurdi Effect; Peran Media Sosial Dengan Solidaritas Kemanusiaan di Jerman. Jurnal Analisis Hubungan Internasional, 21-30.

[7]. Rysaback-Smith, H. (2015). History and Principle of Humanitarian Action. Eergency Medicine Association of Turkey, 5-7.

[8]. Associations, U. O. (1986). Yearbook of International Organizations 23rd edition. Brussels: Union of International Association.

[9]. Tzu, S. (2013). The Art of War. Orange Publishing.

[10]. Brubacher, B. (2004, September 28). Moral and Practical Challenges to NGO Neutrality. Retrieved September 17, 2018, from INTRAC (International NGO Training and Research Centre): https://www.globalpolicy.org/component/content/article/176/31283.html

[11]. Commision, E. (2018, September 7). Syria. Retrieved September 17, 2018, from European Commision: http://ec.europa.eu/echo/news/syria-crisis-europeancommission-announces-445-million-humanitarian-aiden 
[12]. Eleanor Davey, John Borton, Matthew Foley. (2013, june). HPG Working Paper. Retrieved September 15, 2018, from odi.org: https://www.odi.org/publications/7535global- history\%20humanitarian-action

[13]. ICRC. (1994). Code of Conduct. Retrieved September 17, 2018, from Ifrc: https://media.ifrc.org/ifrc/who-we-are/the-movement/code-of-conduct/

[14]. Nations, U. (1991, December). UN Resolution 46/182. Retrieved August 15, 2018, from Strengthening of the coordination of humanitarian emergency assistence of the United Nations: http://www.un.org/documents/ga/res/46/a46r182.htm

[15]. Perman, F. E. (2018, March 21). Dapur ACT di Ghouta Produksi 20 Ribu Paket Makanan Perhari. Retrieved August 9, 2018, from: https://www.republika.co.id/berita/duniaislam/wakaf/18/03/08/p59szg368-dapur-act-dighouta-produksi-20-ribu-paket-makanan-per-hari

[16]. ACT News. (2018, August 2). Hari ini Pabrik Roti ACT untuk Suriah Beroprasi. Retrieved August 2, 2018, from Archive.act.id: https://archive.act.id/id/whatshappening/view/3554/hari-ini-pabrik-roti-act-untuk-suriah-beroperasi 